\title{
PENGARUH PEMBERIAN JUS APEL FUJI (MALUS DOMESTICA) DAN SUSU TINGGI KALSIUM RENDAH LEMAK TERHADAP KADAR TRIGLISERIDA PADA TIKUS SPRAGUE DAWLEY HIPERKOLESTEROLEMIA
}

\author{
Ratna Yolanda Agustina, Muhammad Sulchan ${ }^{*}$ \\ Program Studi Ilmu Gizi Fakultas Kedokteran Universitas Diponegoro \\ J1.Dr.Sutomo No.18, Semarang, Telp (024) 8453708, Email : gizifk@ undip.ac.id
}

\begin{abstract}
Background: One of the risk factors for coronary heart disease (CHD) is hypercholesterolemia, a condition in which high levels of cholesterol in the blood. Hypercholesterolemia is closely connected with triglyceride levels in the blood when high triglycerides in the blood will lead to atherosclerosis. Fuji apples contain substances such as phytochemicals quercetin, catechin, phloridzin and chlorogenic acid which is known to lower triglyceride levels in the blood. Calcium in milk is useful for weight loss and decrease fat synthesis and prevent hypercholesterolemia. This study aimed to determine the effect of fruit juice fuji apples high and calcium low fat milk to lower triglyceride levels in the Sprague Dawley rat hypercholesterolemia.

Methods: This study is a true experimental study with pre-post test randomized control group design that uses 30 rats of Sprague Dawly dyslipidemia. Groupings were randomly divided into 6 groups: negative control group who were given standard feed, given the positive control standard and high-fat feed, two groups were given standard feed, high fat feed and fuji apple juice with the peels and without peels fuji apple juice, the two groups other received standard feed, feed high cholesterol, high calcium low fat milk and juice fuji apple with the peels and without peels for 14 days. Data were analyzed by Paired t-test and ANOVA.

Results: Changes in triglyceride levels of negative control group, positive control, treatment of apple peels juice, apple juice without peel, apple peels juice and high-calcium milk, apple juice without peels and high-calcium milk is -10.25 respectively $(p=0.296) ; 4.25(p=0.762) ;-34.25(p=0.005), 7.50(p=0.017), 5.20(p=0.782), 21.75(p$ $=0,68)$. There is a difference based on ANOVA test changes in triglyceride levels between groups $(p=0.037)$.

Conclusion: fuji apple juice without the skins for 14 days can lower triglyceride levels significantly, but the provision of fuji apple juice with the peels can increase triglyceride levels significantly.

Keywords: fuji apple juice; high calcium low fat milk; quercetin; pectin; calcium triglycerides
\end{abstract}

\begin{abstract}
ABSTRAK
Latar Belakang : Salah satu faktor risiko terjadinya penyakit jantung koroner (PJK) adalah hiperkolesterolemia, suatu kondisi dimana tingginya kadar kolesterol dalam darah. Hiperkolesterolemia erat hubungannya dengan kadar trigliserida di dalam darah apabila trigliserida dalam darah tinggi akan memicu timbulnya atherosklerosis. Apel fuji mengandung zat fitokimia seperti quercetin, catechin, phloridzin dan asam klorogenik yang diketahui dapat menurunkan kadar trigliserida dalam darah. Kalsium dalam susu berguna untuk menurunkan berat badan dan menurunkan sintesis lemak dan mencegah hiperkolesterolemia. Penelitian ini bertujuan untuk mengetahui pengaruh jus buah apel fuji dan susu tinggi kalsium rendah lemak terhadap kadar trigliserida pada tikus Sprague Dawley hiperkolesterolemia.
\end{abstract}

Metode: Penelitian ini merupakan penelitian true experimental dengan pre-post test randomized control group design yang menggunakan 30 ekor tikus Sprague Dawely hiperkolesterolemia. Dibagi secara acak menjadi 6 kelompok yaitu kelompok kontrol negatif yang hanya diberikan pakan standart, kontrol positif yang diberikan pakan standart dan tinggi lemak, dua kelompok diberikan pakan standart, pakan tinggi lemak dan jus apel fuji dengan kulit dan jus apel fuji tanpa kulit, dua kelompok lainnya mendapat pakan standart, pakan tinggi kolesterol, susu tinggi kalsium rendah lemak dan jus apel fuji dengan kulit dan tanpa kulit selama 14 hari. Data dianalisis dengan uji Paired t-test dan Anova.

Hasil: Perubahan kadar trigliserida kelompok kontrol negatif, kontrol positif, perlakuan jus apel kulit, jus apel tanpa kulit, jus apel kulit dan susu tinggi kalsium, jus apel tanpa kulit dan susu tinggi kalsium secara berurutan adalah-10,25 ( $p=0,296) ; 4,25$ ( $p=0,762) ;-34,25$ ( $p=0,005), 7,50(p=0,017), 5,20 \quad(p=0,782), 21,75(p=0,68)$. Berdasarkan uji Anova terdapat perbedaan perubahan kadar trigliserida antar kelompok $(p=0,037)$.

Simpulan : Pemberian jus apel fuji tanpa kulit selama 14 hari dapat menurunkan kadar trigliserida secara signifikan, namun pemberian jus apel fuji dengan kulit dapat menaikan kadar trigliserida secara signifikan.

Kata kunci : Jus apel fuji; susu tinggi kalsium rendah lemak;quercetin; kalsium; trigliserida

\footnotetext{
${ }^{*}$ Penulis Penanggungjawab
} 


\section{PENDAHULUAN}

Salah satu faktor risiko terjadinya penyakit jantung koroner (PJK) adalah hiperkolesterolemia, suatu kondisi dimana tingginya kadar kolesterol dalam darah. Hiperkolesterolemia erat hubungannya dengan kadar trigliserida di dalam darah apabila trigliserida dalam darah tinggi akan berkontribusi memicu timbulnya atherosklerosis. ${ }^{1}$ Data dari Survei Rumah Tangga Nasional Kesehatan Indonesia telah menunjukkan bahwa kematian akibat penyakit kardiovaskular meningkat $9,7 \%$ pada tahun $1986 ; 15,5 \%$ di tahun 1992; dan 18,9\% di tahun 1995 dan menjadi 26,3\% pada tahun 2001. Melalui data tersebut penyakit kardiovaskular ditempatkan sebagai penyebab kematian tertinggi di Indonesia. ${ }^{2}$ Pengaturan diet dengan mengurangi asupan makanan dan minuman yang berlemak dapat membantu mengobati hiperkolestrolemia. ${ }^{1}$

Penggunaan zat fitokimia seperti quercetin sebagai suplemen memiliki efek proteksi terhadap dislipidemia dan merupakan salah satu alternatif pengurangan angka kejadian penyakit kardiovaskuler. Salah satu sumber makanan dengan efek hipolipidemia yang dianjurkan adalah apel fuji dan susu tinggi kalsium rendah lemak. ${ }^{3,4,5}$ Sebuah penelitian menunjukan penurunan yang signifikan dan progresif dari jus buah apel fuji terhadap kadar trigliserida kelinci dengan dosis 10 $\mathrm{ml}$ jus apel/hari selama 60 hari. $^{6}$ Pada penelitian lain menunjukan bahwa susu tinggi kalsium rendah lemak dapat menurunkan serum trigliserida dan kolesterol LDL tanpa mempengaruhi kolesterol HDL. ${ }^{5}$ Perpaduan antara buah apel fuji (malus domestica) dengan susu tinggi kalsium rendah lemak berpotensi dalam mengendalikan kadar trigliserida dan dalam jangka panjang dapat menekan prevalensi penyakit kardiovaskular.

Dalam penetian kali ini buah apel fuji ( Malus domestica ) dikombinasikan dengan susu tinggi kalsium rendah lemak. Sebuah penelitian yang dilakukan di Milan, Italy susu yang kaya akan kalsium yang diberikan pada pasien obesitas secara signifikan dapat menurunkan berat badan dengan tingkat keberhasilan $60-80 \%$, karena kerja kalsium berhubungan dengan peran intraseluler kalsium dalam metabolisme pada jaringan. Pada sel pankreas, penurunan konsentrasi kalsium dalam intraseluler akan menurunkan produksi insulin yang akan berpengaruh terhadap penurunan lipogenesis dan peningkatan lipolisis dalam adiposit. Kombinasi kedua ini berperan dalam penurunan simpanan lemak dalam jaringan adiposa, sehingga konsumsi kalsium yang cukup dalam diet harian dianjurkan untuk mencegah hiperkolesterolemia. ${ }^{9}$

\section{METODE PENELITIAN}

Penelitian yang dilakukan di Laboratorium Parasitologi Fakultas Kedokteran Universitas Diponegoro ini merupakan penelitian experimental laboratorik jenis randomized control groups prepost design. Variabel bebas pada penelitian ini adalah pemberian jus apel fuji dengan atau tanpa kulit dan susu tinggi kalsium rendah lemak sedangkan variabel terikat dalam penelitian ini adalah kadar trigliserida.

Sampel penelitian yang digunakan adalah tikus jantan galur Sprague Dawley umur 8 minggu dengan berat badan rata-rata 150- 200 gram yang diperoleh dari Laboratorium Farmasi Universitas Gadjah Mada, Yogyakarta. Besar sampel minimal dalam penelitian ini ditentukan berdasarkan rumus Federer $(\mathrm{t}-1)(\mathrm{n}-1) \geq 15, \mathrm{t}$ merupakan jumlah kelompok perlakuan sedangkan $n$ merupakan besar sampel setiap kelompok perlakuan sehingga didapatkan hasil 4 ekor. ${ }^{12}$ Pada penelitian ini menggunakan 5 ekor tikus untuk setiap kelompok perlakuan untuk mengantisipasi terjadinya drop out, sehingga jumlah tikus yang digunakan adalah 30 ekor. Kelompok pada penelitian ini terdiri dari kontrol negatif, kontrol positif, kelompok perlakuan dosis 4,62g jus apel fuji dengan kulit, kelompok perlakuan dosis 4,62g jus apel fuji tanpa kulit, kelompok perlakuan dosis 4,62g jus apel fuji dengan kulit diambah dosis $6,16 \mathrm{ml}$ susu tinggi kalsium rendah lemak dan kelompok perlakuan dosis 4,6g jus apel fuji tanpa kulit ditambah dosis $6,16 \mathrm{ml}$ susu tinggi kalsium rendah lemak. Jus apel dan susu diberikan menggunakan sonde dengan frekuensi jus apel 1 kali dan susu 2 kali dalam sehari.

Seluruh sampel diadaptasi terlebih dahulu selama 7 hari dengan menggunakan pakan standar BR-2 sebanyak 20 gram/ekor/hari dan minum ad libithum. Selanjutnya, sampel dibagi menjadi 6 kelompok dengan simple random sampling. Kelompok kontrol negatif diberikan pakan standar sampai akhir penelitian, kelompok kontrol positif dan kelompok perlakuan diberi pakan standar serta pakan tinggi kolesterol selama 14 hari untuk membuat tikus menjadi hiperkolesterolemia. Sebelum memasuki tahap intervensi dilakukan pengambilan darah awal.

Pakan tinggi kolesterol berupa otak sapi yang telah dikukus lalu diblender dan diberikan melalui sonde sebanyak $10 \%$ dari pakan standar atau $2 \mathrm{ml} / \mathrm{ekor} / \mathrm{hari}$. Jus apel yang diberikan berasal 
dari apel fuji yang dihaluskan menggunakan blender, kemudian ditimbang sebanyak 4,62 mg, setelah itu disaring dan diberikan melalui sonde. Ampas kulit apel diberikan pada kelompok perlakuan jus apel fuji dengan kulit. Ampas apel diberikan bersama pakan standart tikus.

Pengambilan darah sampel sebelum intervensi dimaksudkan untuk melihat kadar trigliserida setelah pemberian pakan tinggi kolesterol selama 14 hari. Pengambilan sampel darah akhir untuk melihat kadar trigliserida setelah pemberian jus apel fuji dengan atau tanpa kulit dan susu tinggi kalsium rendah lemak selama 14 hari. Sampel darah diambil sebanyak $2 \mathrm{ml}$ melalui pleksus retroorbitalis. Data yang diperoleh diolah dengan program komputer. Semua data tersebut diuji normalitasnya dengan uji Saphiro Wilk. Perbedaan kadar trigliserida sebelum dan sesudah perlakuan menggunakan uji statistik parametrik Paired t-test (normal). Perbedaan perubahan kadar trigliserida dari keenam kelompok perlakuan dianalisis menggunakan uji statistik parametrik One Way Anova (normal).

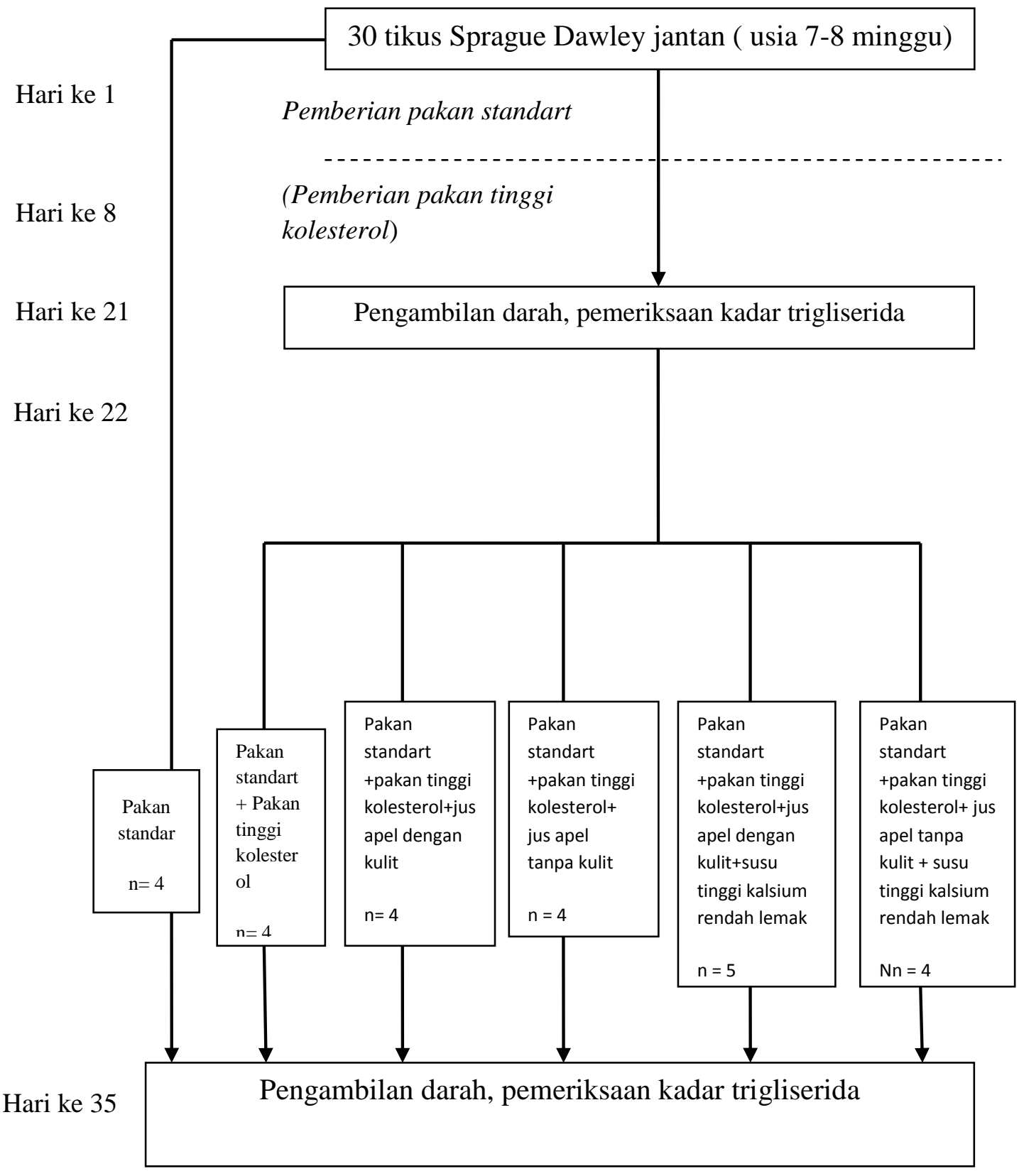

Gambar 1. Alur Kerja 
HASIL PENELITIAN

Kadar trigliserida sebelum dan sesudah perlakuan

Jumlah sampel pada penelitian ini sebanyak 30 ekor kemudian dibagi menjadi 6 kelompok. Terdapat 5 ekor tikus pada masing masing kelompok kecuali kelompok perlakuan (P3) sehingga jumlah sampel menjadi 25 ekor.
Penimbangan berat badan tikus dilakukan setiap minggu dan penimbangan sisa pakan dilakukan setiap hari. Sampel dipelihara pada kandang individu dengan suhu $28-32^{\circ} \mathrm{C}$ dan siklus pencahayaan 12 jam. Perbedaan berat badan dan asupan pakan tikus dapat dilihat pada Tabel 1 dan 2.

Tabel 1. Perbedaan berat badan tikus sebelum dan sesudah perlakuan

\begin{tabular}{|c|c|c|c|c|c|}
\hline \multirow[t]{2}{*}{ Kelompok } & \multirow[t]{2}{*}{$\mathbf{n}$} & \multicolumn{2}{|c|}{ Berat Badan Tikus } & \multirow[t]{2}{*}{$\Delta$} & \multirow[t]{2}{*}{$p$} \\
\hline & & Sebelum (g) & Setelah $(\mathbf{g})$ & & \\
\hline $\mathrm{K}-$ & 4 & $176,1 \pm 10,09^{a}$ & $219,6 \pm 18,94^{b}$ & $43,5 \pm 2,37$ & $0,035^{\mathrm{c}} *$ \\
\hline $\mathrm{K}+$ & 4 & $182,0 \pm 7,96^{\mathrm{a}}$ & $215,6 \pm 16,8^{b}$ & $33,6 \pm 9,39$ & $0,336^{\mathrm{c}}$ \\
\hline P1 (apel+kulit) & 4 & $162,4 \pm 20,76^{\mathrm{a}}$ & $194,0 \pm 28,15^{\mathrm{b}}$ & $31,6 \pm 10,7$ & $0,010^{\mathrm{c} *}$ \\
\hline P2 (apel) & 4 & $178,9 \pm 4,97^{\mathrm{a}}$ & $209,8 \pm 6,65^{\mathrm{b}}$ & $30,9 \pm 9,71$ & $0,008^{\mathrm{c} *}$ \\
\hline P3 (apel+kulit+susu) & 5 & $181,6 \pm 8,18^{\mathrm{a}}$ & $218,9 \pm 17,2^{\mathrm{b}}$ & $37,3 \pm 24,75$ & $0,043^{\mathrm{c} *}$ \\
\hline P4 (apel+susu) & 4 & $179,8 \pm 9,26^{\mathrm{a}}$ & $212,8 \pm 9,91^{\mathrm{b}}$ & $33,0 \pm 3,44$ & $0,000^{\mathrm{c}} *$ \\
\hline
\end{tabular}

${ }^{\mathrm{a}} \mathrm{Uji}$ Kruskall Wallis ${ }^{\mathrm{b}}$ Uji One Way Anova ${ }^{\mathrm{c}}$ Paired t-test

*memiliki perbedaan yang bermakna $(\mathrm{p}<0,05)$

Bedasarkan data yang ditunjukkan dari tabel 1, diketahui bahwa terdapat perbedaan yang signifikan berat badan tikus sebelum dan sesudah perlakuan antara berat badan sebelum dan berat badan setelah perlakuan pada semua kelompok kecuali kelompok $\mathrm{K}+(\mathrm{p}>0,05)$.

Tabel 2. Perbedaan asupan pakan tikus sebelum dan sesudah perlakuan

\begin{tabular}{|c|c|c|c|c|c|}
\hline \multirow[t]{2}{*}{ Kelompok } & \multirow[t]{2}{*}{$\mathbf{n}$} & \multicolumn{2}{|c|}{ Asupan Pakan } & \multirow[t]{2}{*}{$\Delta$} & \multirow[t]{2}{*}{$p$} \\
\hline & & Sebelum (gr) & Selama (gr) & & \\
\hline $\mathrm{K}-$ & 4 & $19,1 \pm 0,20^{\mathrm{a}}$ & $19,2 \pm 0,19^{\mathrm{a}}$ & $0,1 \pm 0,17$ & $0,388^{\mathrm{b}}$ \\
\hline $\mathrm{K}+$ & 4 & $18,5 \pm 0,35^{\mathrm{a}}$ & $19,0 \pm 0,07^{\mathrm{a}}$ & $0,5 \pm 0,39$ & $0,089^{\mathrm{b}}$ \\
\hline P1 (apel+kulit) & 4 & $19,0 \pm 0,14^{\mathrm{a}}$ & $19,0 \pm 0,07^{\mathrm{a}}$ & $-0,0 \pm 0,18$ & $0,987^{\mathrm{b}}$ \\
\hline P2 (apel) & 4 & $19,2 \pm 0,25^{\mathrm{a}}$ & $19,1 \pm 0,09^{\mathrm{a}}$ & $-0,1 \pm 0,20$ & $0,432^{\mathrm{b}}$ \\
\hline P3 (apel+kulit+susu) & 5 & $18,7 \pm 0,41^{\mathrm{a}}$ & $17,4 \pm 0,16^{\mathrm{a}}$ & $-1,3 \pm 0,36$ & $0,001^{\mathrm{b} *}$ \\
\hline P4 (apel+susu) & 4 & $18,5 \pm 0,44^{\mathrm{a}}$ & $17,3 \pm 0,26^{\mathrm{a}}$ & $-1,2 \pm 0,47$ & $0,013^{\mathrm{b} *}$ \\
\hline
\end{tabular}

${ }^{\mathrm{a}}$ Uji Kruskall Wallis ${ }^{\mathrm{b}}$ Paired $t$-test ${ }^{*}$ memiliki perbedaan yang bermakna $(\mathrm{p}<0,05)$

Data yang ditunjukan pada tabel 2, diketahui terdapat perbedaan yang signifikan pada asupan pakan sebelum dan sesudah perlakuan pada kelompok P3 dan kelompok P4 . Selisih asupan pakan sebelum dan sesudah paling tinggi terdapat pada kelompok P3, yaitu 1,32 gram dan paling rendah pada kelompok P1 yaitu 0,00 gram

Pemeriksaan kadar trigliserida dilakukan pada sebelum dan setelah perlakuan. Berikut gambaran rerata kadar trigliserida yang ditampilkan pada tabel 3 .

Tabel 3. Perbedaan kadar trigliserida sebelum dan setelah perlakuan

\begin{tabular}{|c|c|c|c|c|c|}
\hline \multirow[t]{2}{*}{ Kelompok } & \multirow[t]{2}{*}{$\mathbf{n}$} & \multicolumn{2}{|c|}{$\begin{array}{c}\text { Rerata Kadar trigliserida } \\
(\mathbf{m g} / \mathbf{d l})\end{array}$} & \multirow[t]{2}{*}{$\Delta$} & \multirow[t]{2}{*}{$p$} \\
\hline & & Sebelum & Setelah & & \\
\hline K- & 4 & $100,5 \pm 33,45^{\mathrm{a}}$ & $110,7 \pm 35,04^{\mathrm{a}}$ & $10,2 \pm 16,23$ & $0,296^{\mathrm{b}}$ \\
\hline K+ & 4 & $107,7 \pm 49,78^{\mathrm{a}}$ & $103,5 \pm 37,67^{\mathrm{a}}$ & $-4,2 \pm 25,63$ & $0,762^{\mathrm{b}}$ \\
\hline P1 (apel+kulit) & 4 & $71,2 \pm 8,38^{\mathrm{a}}$ & $105,5 \pm 15,78^{a}$ & $34,2 \pm 9,06$ & $0,005^{\mathrm{b} *}$ \\
\hline P2 (apel) & 4 & $88,7 \pm 21,89^{\mathrm{a}}$ & $81,2 \pm 24,29^{\mathrm{a}}$ & $-7,5 \pm 3,10$ & $0,017^{\mathrm{b} *}$ \\
\hline P3 (apel+kulit+susu) & 5 & $78,6 \pm 21,14^{\mathrm{a}}$ & $73,4 \pm 21,52^{\mathrm{a}}$ & $-5,2 \pm 39,27$ & $0.782^{b}$ \\
\hline P4 (apel+susu) & 5 & $94 \pm 21,6^{\mathrm{a}}$ & $72,2 \pm 21,83^{\mathrm{a}}$ & $-21,7 \pm 8,38$ & $0,68^{\mathrm{b}}$ \\
\hline
\end{tabular}

${ }^{\mathrm{a}}$ Uji One Way Anova ${ }^{\mathrm{b}} \mathrm{Uji}$ Paired t-test 
Hasil analisis menunjukkan adanya penurunan kadar trigliserida bermakna pada kelompok P2. Kenaikan kadar trigliserida bermakna terjadi pada
Kelompok P1. Berdasarkan, uji one way anova menunjukkan bahwa tidak terdapat perbedaan kadar trigliserida antara keenam kelompok

Tabel 4. Perbedaan perubahan asupan pakan, berat badan, kadar trigliserida pada enam kelompok perlakuan.

\begin{tabular}{lccccccc}
\hline \multicolumn{1}{c}{ Rerata } & $\mathrm{K}-$ & $\mathrm{K}+$ & $\mathrm{P} 1$ & $\mathrm{P} 2$ & $\mathrm{P} 3$ & $\mathrm{P} 4$ & $p$ \\
& & & & & & & \\
$\Delta$ Asupan pakan & $0,08 \mathrm{~g}$ & $0,49 \mathrm{~g}$ & $0,00 \mathrm{~g}$ & $-0,09 \mathrm{~g}$ & $-1,32 \mathrm{~g}$ & $-1,26 \mathrm{~g}$ & $0,002^{*}$ \\
$\Delta$ Berat Badan & $343,52 \mathrm{~g}$ & $33,58 \mathrm{~g}$ & $31,58 \mathrm{~g}$ & $30,82 \mathrm{~g}$ & $37,40 \mathrm{~g}$ & $33,01 \mathrm{~g}$ & 0,976 \\
$\begin{array}{l}\Delta \text { Kadar } \\
\text { trigliserida }\end{array}$ & 10,25 & - & 34,25 & $-7,50$ & $-5,20$ & $-21,75$ & $0,037^{*}$ \\
\hline
\end{tabular}

Uji post hoc: K- vs $\mathrm{P} 4 p=0,056, \mathrm{~K}+$ vs $\mathrm{P} 1 p=0,24, \mathrm{P} 1$ vs $\mathrm{P} 2 p=0,16$, $\mathrm{P} 1$ vs $\mathrm{P} 3 p=0,16$, $\mathrm{P} 4$ vs $\mathrm{P} 1 p=$ 0,002

Hasil analisis uji one way anoval uji Kruskall Wallis, diketahui asupan pakan dan kadar trigliserida

mempunyai nilai $\mathrm{p}<0,05$. Hal ini menunjukkan bahwa terdapat perbedaan pengaruh kadar trigliserida dan berat badan pada keenam kelompok, sedangkan pada berat badan terdapat perbedaan pergaruh pada keenam kelompok.

\section{PEMBAHASAN}

\section{Kandungan Zat Jus Buah Apel}

Kandungan zat gizi buah apel fuji telah diteliti sebelumnya mengandung beberapa zat fitokimia yang berupa quercetin, catechin, phloridzin dan asam klorogenik yang diduga dapat menurunkan kadar trigliserida dalam darah. Kandungan serat larut dalam 100 gr buah apel fuji atau yang lebih dikenal dengan pektin adalah sebanyak $7,1 \%$. ${ }^{8,9,10}$

Perbedaan komposisi pektin pada buah apel fuji terdapat pada kulit dan daging buahnya, yaitu sekitar 17,44\%/berat buah pada kulit dan $15,3 \%$ berat pada buah apel. ${ }^{11}$ Penelitian terdahulu menyatakan dalam kulit apel lebih banyak mengandung functional fiber dan merupakan jenis karbohidrat. Apel merupakan bahan baku yg sering digunakan dalam produk pektin komersial. Menurut penelitian pektin pada kulit apel dapat mengurangi kandungan kolesterol LDL dan trigliserida sebanyak $10 \%$ yang merupakan penyebab penyakit jantung koroner. ${ }^{10}$

\section{Kandungan Susu Tinggi kalsium Rendah Lemak}

Sebuah penelitian dilakukan Tavani dkk pada penderita hiperkolesterolemia menunjukkan bahwa kadar kolesterol total, LDL, dan trigliserida dalam darah menurun secara signifikan setalah mengkonsumsi susu tinggi kalsium rendah lemak tinggi kalsium. Susu tinggi kalsium rendah lemak hanya mengandung 0,1 gram lemak tiap 100gram.

Peranan kalsium untuk menurunkan berat badan dan kolesterol telah terungkap secara empiris, walaupun sebagai fungsi utama kalsium dibutuhkan untuk pertumbuhan tulang dan gigi. Konsumsi kalsium yang cukup dalam diet harian dianjurkan untuk menurunkan berat badan dan menurunkan sintesis lemak dan mencegah hiperkolesterol. Hasil penelitian tersebut juga menunjukkan kalsium dapat menurunkan berat badan seserang dengan obesitas dengan tingkat keberhasilan 60-80\%.

\section{Berat badan subjek}

Berat badan sebelum dan sesudah perlakuan mengalami peningkatan yang secara statistik bermakna kecuali pada kelompok kontrol positif secara statisitik tidak bermakna. Dari hasil pengukuran berat badan menunjukkan bahwa tidak terdapat perbedaan berat badan sebelum dan selama perlakuan antar kelompok. Peningkatan berat badan yang paling tinggi terdapat pada kelompok kontrol negatif yaitu $176,14 \mathrm{~g}$ menjadi 219,66g dikarenakan kelompok kontrol negatif pakan standar dengan jumlah yang sama dengan seluruh sampel yaitu sebesar 20 gram,namun tidak adanya faktor stress pada kelompok kontrol negatif menyebabkan berat badan terus bertambah.

\section{Pakan Tinggi Kolesterol}

Pada penelitian ini pengkondisian tikus menjadi hiperkolesterolemia menggunakan pakan 
tinggi kolesterol yaitu otak sapi. Pemilihan otak sapi sebagai pakan tinggi kolesterol dikarenakan kadar kolesterol yang terdapat pada otak sapi lebih relatif tinggi yaitu sebanyak $2000 \mathrm{mg} / 100$ gram bahan makanan, selain itu otak sapi memiliki kandungan lemak sebanyak 52,2\% ${ }^{13}$ Pemberian otak sapi selama 14 hari dapat mengakibatkan kondisi hiperkolesterolemia dengan meningkatkan kadar kolesterol total, kolesterol LDL, trigliserida serta menurunkan kolesterol HDL pada tikus Wistar jantan. ${ }^{13}$ Untuk mengetahui apakah pemberian pakan tinggi kolesterol dapat mempengaruhi kadar trigliserida sampel yaitu dengan membandingkan kadar trigliserida kelompok yang tidak diberi pakan tinggi kolesterol $(\mathrm{K}(-))$ dengan kelompok yang diberi pakan tinggi kolesterol (K(+), P1, P2,P3,P4).

\section{Kadar trigliserida sebelum dan sesudah pemberian jus Apel Fuji dan Susu Tinggi Kalsium Rendah Lemak}

Hasil dari penelitian menunjukan pada kelompok $\mathrm{K}(-)$ yang hanya diberikan pakan standart dan air minum secara ad libitlum, namun pada kelompok ini diketahui rata rata kadar trigliserida paling tinggi diantara kelompok yang lainnya. Diduga kurangnya faktor stess pada tikus kelompok K(-) yang menyebabkan asupan pakan tikus menjadi lebih besar menyebabkan kenaikan berat badan pada tikus dan meningkatkan produksi lipoprotein yang menyebabkan kenaikan kadar trigliserida.Pada kelompok perlakuan $\mathrm{K}+$ terjadi penurunan trigliserida namun tidak signifikan diduga karena terdapat 2 ekor ekor tikus yang terserang jamur yang tumbuh di leher tikus yang menyebabkan berat badan tikus lebih kecil diantara tikus tikus yang lain akibatnya menyebabkan menurunnya produksi lipoprotein yang mengandung trigliserida.

Terdapat perbedaan kadar trigliserida sebelum dan sesudah pemberian jus apel fuji dan susu tinggi kalsium rendah lemak. Penurunan kadar trigliserida bermakna terdapat pada kelopok perlakuan P2 dari $88,75 \mathrm{mg} / \mathrm{dl}$ sebelum perlakuan menjadi $81,25 \mathrm{~mm} / \mathrm{dl}$ setelah perlakuan, namun terjadi kenaikan kadar trigliserida secara bermakna pada kelompok perlakuan P1 yang seharusnya mengalami penurunan dari $71,25 \mathrm{mg} / \mathrm{dl}$ sebelum perlakuan menjadi $105,5 \mathrm{mg} / \mathrm{dl}$ setelah perlakuan

Pada kelompok intervensi P2 diketahui penurunan kadar trigliserida tikus paling tinggi, hal ini karena pemberian jus apel fuji tanpa kulit yang mengandung quercetin, catechin, phloridzin dan asam klorogenik. Peran quercetin sebagai hipolipidemik ialah mengurangi akumulasi lemak dalam hati serta menghambat produksi lipoprotein agar tidak berlebih yang dapat menurunkan kadar trigliserida dalam darah. ${ }^{12}$ Kelompok $\mathrm{P} 4$ juga mengalami penurunan dari sebelum perlakuan kadar trigliserida tikus $94 \mathrm{mg} / \mathrm{dl}$ menjadi 72,25 $\mathrm{mg} / \mathrm{dl}$ setelah intervensi hal ini diduga karena pemberian jus apel fuji tanpa kulit dan dikombinasikan dengan susu tinggi kalsium rendah lemak. Selain kandungan quercetin yang dapat menghambat produksi lipoprotein juga diduga karena kalsium tinggi dalam susu yang mekanismenya akan mengalami penurunan proses lipogenesis dan peningkatan lipolisis, Kombinasi kedua ini berperan dalam penurunan simpanan lemak dalam jaringan adiposa. ${ }^{12,13,14}$

Kenaikan kadar trigliserida terjadi pada kelompok P1 yang diberikan perlakuan menggunakan jus apel fuji dengan kulit, hal ini dimungkinkan karena terdapat residu pestisida diazinon dan dimetoat dalam kulit apel yang masih tertinggal setelah pencucian. ${ }^{16}$ Bahan kimia dari kandungan pestisida dapat meyebabkan gangguan fungsi hati karena bersifat hipototoksik. Interaksi antara toksikan dari kulit buah apel dengan struktur reseptor yang ada di sel hati menyebabkan terjadinya kerusakan pada membran sel. Di dalam membran sel terdapat enzim lipoprotein lipase yang bekerja menghidrolisis trigliserida untuk melepaskan asam lemak. Kerusakan membran sel tersebut menyebabkan inaktivasi enzim lipoprotein lipase sehingga kadar trigliserida dalam plasma tinggi karena trigliserida tidak dihidrolisis.. Hepatotoksik dapat terjadi akibat disfungsi mitokondria dimana mitokondria merupakan tempat berlangsunya proses oksidasi asam lemak. Asam lemak hasil hidrolisis trigliserida oleh lipoprotein lipase yang ada di membran sel akan masuk kedalam mitokondria untuk proses oksidasi asam lemak atau diubah kembali menjadi trigliserida. Apabila proses oksidasi asam lemak menurun akibat disfungsi mitokondria maka asam lemak tidak dapat dijadikan bahan bakar metabolisme dan akan diubah menjadi trigliserida kembali. Hal ini mengakibatkan peningkatan kadar trigliserida plasma. ${ }^{17,18}$

Pemberian jus apel fuji dengan kulit lainnya terdapat pada kelompok P3 namun dikombinasikan dengan pemberian susu tinggi kalsium rendah lemak. Pada kelompok perlakuan P3 terjadi penurunan trigliserida tetapi tidak signifikan. Hal ini dimungkinkan meskipun residu pestisida pada kulit apel yang berkontribusi menaikan trigliserida dapat ditekan dengan pemberian kalsium tinggi dari susu. Mekanisme kerja kalsium berhubungan 
dengan peran intraseluler kalsium dalam metabolisme pada jaringan. Adanya peningkatan konsumsi kalsium dalam bahan pangan akan menurunkan konsentrasi 1,25- dehidroksi vitamin D3 (1,25 (OH2) D3). Hasilnya akan menyebabkan penurunan pengaturan transfer kalsium ke adiposa dan pankreas. Pada adiposa penurunan konsentrasi kalsium intraseluler akan menurunkan enzim asam lemak sintase, penurunan proses lipogenesis, dan peningkatan lipolisis. Pada sel pankreas, penurunan konsentrasi kalsium dalam intraseluler akan menurunkan produksi insulin yang akan berpengaruh terhadap penurunan lipogenesis dan peningkatan lipolisis dalam adiposit. Kombinasi kedua ini berperan dalam penurunan simpanan lemak dalam jaringan adiposa sehingga dapat menurunkan kadar trigliserida dalam darah. ${ }^{14,15,19}$

\section{SIMPULAN}

Pemberian jus apel fuji tanpa kulit kulit selama 14 hari dapat menurunkan kadar trigliserida secara signifikan, namun pemberian jus apel fuji dengan kulit selama 14 hari tidak dapat menurunkan kadar trigliserida.

\section{DAFTAR PUSTAKA}

1. Kalim Harmani, Mamentu Kaligis. The risk factors profile of coronary heart disease in dyslipidemic patients :Results from a survey in 13 cities in Indonesia, Department of Cardiology. Faculty of Medicine University of Indonesia. Jakarta. Indonesia : 2001

2. Ministry Of Healt, Republik Of Indonesia, Indonesia Healt Profile 2008, Jakarta : 2010

3. Kreisberg RA, Oberman albert, Medical Management Of Hyperlipidemia/Dislipidemia. J Clin Endocrinol Metab. Birmingham, Alabama $35205: 2003$

4. Boyer Jeanelle, Liu RH. Apple Phytochemical And Their Healt Benefits, Nutritioin Journal, New York : 2004

5. Soedamah SS, Geleijnse JM. Milk and dairy consumption and incidence of cardiovascular diseasesand all-cause mortality: dose-response meta-analysis of prospectivecohort studies. Am J Clin Nutr : 2011

6. Setorki M, Asgari S, Eidi A, Rohani AH. Effects of apple juice on risk factors of lipid profile, inflammation and coagulation, endothelial markers and atherosclerotic lesions inhigh cholesterolemic rabbits. Lipids in Health and Disease, Isfahan : 2009

7. Tavani A, Gallus S, Negri E, Vecchia AL. Milk Dairy Product And Coronary Heart Disease. J Epidemiol Community Health 2002;56:471-472

8. Omole JO, Ighodaro OM. Comparative Studies Of The Effect Of Egg Yolk, Oats, Apple and Wheat
Bran on Serum Lipid Profile of Wistar Rats. ISRN Nutrition. Nigeria : 2012

9. Gropper SS, Jack L.Smith, James L.Groff. Advance Nutrition And Human metabolism 5th edition.. Wadsworth Cenage Learning. Belmont CA : 2009

10. Jensen NA, Tine Buch, Gitte Ravn, Lars O. Dragsted. The effects of apples on plasma cholesterol levels and cardiovascular risk - a review of the evidence. Journal of Horticultural Science \& Biotechnology (2009) ISAFRUIT Special Issue 34-41

11. Tuhuloula Abubakar, Lestari Budiyarti, Erha Nur Fitriana. Karakterisasi Pektin Dengan Memanfaatkan Limbah Kulit Pisang Menggunakan Metode Ekstraksi. Program Studi Teknik Kimia. Fakultas Teknik, Universitas Lambung Mangkurat : 2013

12. Dewi YR, Santoso LM, Tibrani MM. Uji Efektifitas Perasan Buah Nanas Terhadap Kadar Kolesterol Total Dan Trigliserida Darah Mencit Sserta Sumbangannya Pada Pembelajaran Biologi Di Sekolah Menengah Atas. Pendidikan Biologi FKIP Universitas Sriwijaya : 2009

13. Kusumaningtyas Indah, Arini Pangastuti, Abidin Nur. Pengkayaan pakan Nauplius Artemia dengan korteks Otak Sapi untuk Meningkatkan Kelangsungan Hidup, Pertumbuhan, dan Daya Tahan Tubuh Udang Windu (Penaeus monodon Fab.) Stadium PL 5-PL 18. B i o S MART ISSN: 1411-321XVolume 7, Nomor 2 Oktober 2005

14. Venti CA, Tatarani PA, Salbe AD. Lack of Relationship between Calcium Intake and Body Size in an Obesity-Prone Population. J Am Diet Assoc. 2005;105:1401-1407.

15. Hansel Boris, Nicolle Catherine, Lalane Florent. Effect of low-fat, fermented milk enriched with plant sterols on serum lipid profile and oxidative stress in moderate Hypercholesterolemia. Am J Clin Nutr 2007;86:790-6.

16. Syahbirin G, Hendra Purnama, Djoko Prijono. Residu Pestisida Pada tiga Jenis Buah Impor. Fakultas kimia FMIPA-IPB : 2001

17. Afriyanto. Kajian Keracunan Pestisida Pada Petani Penyemprot Cabe di Desa Candi Kecamatan Bandungan Kabupaten Semarang. Magister Kesehatan Lingkungan Universitas Diponegoro Semarang : 2008

18. Dewanti NA. Hubungan Paparan Merkuri (Hg) Dengan Kejadian Gangguan Fungsi Hati Pada Pekerja Tambang Emas di Desa Jendi Kecamatan Selogiri Kabupaten Wonogiri. Magister Kesehatan Lingkungan Universitas Diponegoro Semarang : 2013

19. Schrager sarina. Dietary Calcium Intake and Obesity. (J Am Board Fam Pract 2005; 18:205210.) 